\title{
Abhūtvāa-bhāva
}

\section{Akiko Osaki}

本無今有有已還無 is the settled theory the Sautrāntika often uses when it attacks the 三世実有 theory and the four phases of the seventy two dharmas ${ }^{1)}$ which the Sarvāstivāda stands for. To examine the meaning of 有 the Sautrāntika holds and to give a definition of it is the purpose of this paper.

The Sanskrit abhütvā, which means "not having existed before", was translated into Chinese 本無. Accordingly the Chinese character 本 means 'before' in the sense of time. 本, however, is not always used as the past, so that it is necessary to clarify the usage of 本 beforehand.

The first examination is the case of the dispute arisen between the Sautrāntika and the Sarvāstivāda on the four phases of the dharmas, i. e. birth, duration, transformation and destruction. The Sautrāntika, criticizing the Sarvāstivāda's stand that the four phases take place simultaneously, says in the Abhidharma-kośa-bhāṣya: "The three (four) phases which take place at the same moment are not perceptible. Those which can not be perceived are not admitted as phases2)." and continues: "The dharma, not having existed before, now comes into existence: this is the phase of the dharma called birth ( $j a t i$ ). The phase 'duration' (sthiti) shows that the dharma exists for a certain period of time. The dharma, during its stay in the present, differs from its preceding and succeeding dharmas: this difference is what is called transformation (anyathätva). The phase 'destruction' (atita) indicates that the dharma will return to non-existence ${ }^{3)}$."

It is understood, therefore, that when the Sautrāntika refers to the four phases of the dharmas, 本 is used in the sense of the future.

Second, in the course of the argument against the 三世実有 theory the Sautrāntika, defining the three modes of time, says, "The future is the state of the dharma which has not yet come into existence. The dharma, after having come into existence, stays for a time: this state means the present. The past 
is the state of the dharma which became non-existent4)." In this case 本 is also used as the future.

Third, the Sautrāntika, disapproving of the first sütra-proof the Sarvāstivāda brings up, refutes, "The eye-organ arises out of nowhere, and after ceasing its function, it returns to non-existence ${ }^{5)}$." 本 shows the past here.

Finally, if the above mentioned statement were said to the Sarvāstivāda's second sütra-proof and the first theory-proof whose standpoints are of epistemology, 本 would have two meanings, the past and the future. And the two are interchangeable in 本.

If the past and the future are interchangeable, the image of time will not be formed; there will be only past dharmas succeeding and arraying in a fixed order and future dharmas scattering in confusion. Therefore, the present (time), being free from the restriction of time, transforms into 'here' (space).

Then the following is the conclusion: 本 is used in three different ways, so that the Sautrāntika's 有 has three aspects: the image of time which runs from past to future, and of time which runs from future to past, and then the standpoint of space.

Having examined 本, we are now ready to consider the Sautrāntika's 有. The theory ‘本無今有有已還無' (The dharmas, not having existed before, come into existence, and after having existed for a while, return to non-existence; Abhütvā bhavati bhütva ca prativigacchati.) is used for explaining the Sautrāntika's doctrine '現在 有体・過未無体' (The present dharmas are existent, the dharmas of the past and the future, non-existent.), and since this doctrine is founded on the theory of the $b \bar{i} j a$, the theory of the $b \bar{i} j a$ ought to be known clearly in order to understand what 有 indicates.

Vasubandhu explains the $b_{\bar{\imath}} j a$ in the Abhidharma-kośa-bhāṣya as follows:

The bijas are the potentialities which the pañca skandhas are endowed with, and which engender their fruits (phala), i, e. the actual dharmas6).

And further he continues:

The effect of man's deeds is produced from the bijas which are in a state of flux, being momentary, producing bijjas similar to themselves, engendering actual dharmas and being permeated by actual dharmas. The active dharmas, at the moment 
of their birth, create and permeate bijjas, and further maintain and increase bijjas. The bijjas thus have a superior power of producing actual dharmas. Hence the continuation (saṃtati), evolution (parināma) and manifestation (veśeșa) of the bijas ${ }^{7}$ ).

The $b_{i} j a s$ are defined to be in the present but different from the actual dharmas. The form of existence of the past dharmas (already destructed) is called 筸有, and the future dharmas (not yet born), 当有. Both the bijas and the dharmas are in the present but the two are different in nature. They coexist being reciprocally cause and effect.

It may be concluded that the Sautrāntika's 有 was set up on the assumption that the $b \bar{i} j a s$ are existent as the transformed dharmas that once have existed (曾有) and as the potential dharmas from which the actual dharmas are to be born in the future (当有), so that 曾有, 当有 and 実有 are interpenetrated on the same level.

It is not insignificant to touch upon the 三世実有 - 法体恒有 doctrine before giving a definition of the Sautrāntika's 有. In the Abhidharma-kośa-bhāṣya the Sarvāstivāda gives two sütra-proofs and two theory-proofs to defend the 三世実 有 theory. These proofs show that the 三世実有 theory was set up from three different points of view: religious, moral and epistemological viewpoints. In other words, the dharmas must always be existent, so that the dharmas can be the sufficient grounds for establishing the law of cause and effect, and also can be the indispensable factors (indriya and artha) when the vijñanna becomes active. We can say, then, that the words 三世 do not mean the three modes of time (the past, future and present), but they mean the dharmas existing in the three periods of time. As to the Chinese translation, it is suspected that 玄 牀 translated the dharmas of the three periods into the Chinese 三世, because “The dharmas are sometimes called adhvan (世路) $)^{8)}$."

It may be asked, then, if 実有 and 恒有 are the same as nitya (常有). The 三世実有 - 法体恒有 theory was set up in the process of theoretically systematizing the doctrine of Early Buddhism based on the fundamental teaching of the impermanence and non-substantiality of elements. For that reason, 実有 and 恒 有 should be clearly distinguished from 常有. The statement which appears in the Abhidharma-kośa-bhāṣya definitely proves it. It reads: "The Vaibhāṣikas say 
that all dharmas do exist but not eternally, for the dharmas are conditioned 9 )."

The Sarvāstivāda's 有 ought to be considered from two different angles, that is, the four phases of the dharmas which indicate that the dharmas arise from the future and proceed to the past, and that of time which flows from the past towards the future. 有 (the present) does not exist independently; it is linked to the past and the future, not continually but uncontinually, because the dharmas are momentary. In such case, the image of time may be formed in a straight line that runs from past to future.

As to 有 the Sautrāntika professes, it indicates the constant existence of the bijas as well as the dharmas in the present. The past and future dharmas, i. e. the $b_{i j} j a s$, and the present dharmas (actual dharmas) are neither identical nor different. The two are different in nature, so that they can coexist without contradicting each other.

Since the active dharmas and the bijas are existent in the present, it may be held that there is neither past nor future, and that there is only the present 'now'. It must be, however, remembered here that the Sautrāntika's 有 ought to be examined from three different angles. In the case 本 is used in two waysthe present and the future-the image of time does not take shape, because there is a denial of sequence of the dharmas, the one arising after the other in an unchangeable order; there is only a logical relation among a tremendous number of disorderly dharmas.

The conclusion is to be, that the Sautrāntika's 有 (time) involves the concept of space (now). Bhãva, being the original word for the Sautrāntika's 有, happens to suggest it exquisitely. Whether this 有 means "I am the beginning and the end." is another question.

1) The three non-conditioned dharmas in five categories are excluded.

2) The Abhidharma-kośa-bhāṣya (Pradhan), p. 77, $l l .3-5$ 。

3) Ibid., p. $78, l l, 2-4$ 。

4) Ibid., p. 298, ll. 9-10。

5) Ibid., p. 299, ll. 12-14。

6) Ibid., p. 64, $l l .4-6$ 。

7) Ibid., p. 477, $l l .14-18$ 。

8) Ibid., p. 5, l. 3。

9) Ibid., p. 295, $l l .4-5$ 。 